\title{
CHINA - KAZAKHSTAN ECONOMIC COOPERATION AND ONE BELT ONE ROAD CONSTRUCTION
}

\author{
PhD Candidate Gelvig Svetlana \\ China, School of Business, \\ Hunan University of Science and Technology
}

DOI: https://doi.org/10.31435/rsglobal_sr/31032020/6998

\section{ARTICLE INFO}

Received 27 January 2020

Accepted 19 March 2020

Published 31 March 2020

\section{KEYWORDS}

China, Kazakhstan, energy cooperation, trade, international economy, transportation,

"One Belt, One Road".

\begin{abstract}
China and Kazakhstan are long-term partners, which economic relations have reached a new level of the strategic partnership. The "One Belt, One Road" initiative brings new opportunities and challenges for the development of bilateral economic interactions and for the entire Central Asia region. The author made an original analysis of the main components of economic cooperation between the two countries, including energy cooperation, current trade infrastructure and identifying the prospects for implementation of the "One Belt, One Road" initiative. Based on the long-term relationship, strategic partnership and trade cooperation between China and Kazakhstan, construction and combining of the Chinese "One Belt One Road" initiative and Kazakhstan "Bright Road Plan" is the new era for China-Kazakhstan economic development. According to the current research, the construction of this infrastructure will have a direct impact on flows of foreign investments, production development and transport infrastructure. In addition, the construction of the "One Belt, One Road" plan has a great importance for promoting the development of Chinese-Kazakh economic relations and solving difficulties in economic exchanges.
\end{abstract}

Citation: Gelvig Svetlana. (2020) China - Kazakhstan Economic Cooperation and One Belt One Road Construction. Science Review. 3(30). doi: 10.31435/rsglobal_sr/31032020/6998

Copyright: (C) 2020 Gelvig Svetlana. This is an open-access article distributed under the terms of the Creative Commons Attribution License (CC BY). The use, distribution or reproduction in other forums is permitted, provided the original author(s) or licensor are credited and that the original publication in this journal is cited, in accordance with accepted academic practice. No use, distribution or reproduction is permitted which does not comply with these terms.

Introduction. The post-Soviet history of economic cooperation between Kazakhstan and China is showing one of the most impressive progresses. In comparison, smaller than the other major economic powers, the trade volume of about US\$ 300 million in 1992 soared to US \$ 12.2 billion in 2008, a forty-fold increase [1]. The crisis year of 2009 slowed down the rapid expansion of trade cooperation, contracting turnover by 28 percent to US\$ 9.5 billion [1]. This reduction in bilateral trade volume, however, has been less than that with other countries (reduction in Kazakhstan's total foreign trade turnover amounted to over 34 percent). Despite the global crisis, China managed to strengthen its position in the Kazakhstan market.

Nowadays, on the account of rapidly changing conditions of the world's economy, developing countries and their economic strategies are generating special interest. Regional integration is an essential step in the process of economic globalization. Currently, countries of Central Asia are creating joint projects of an impressive scale, and one of the most vivid example is the Chinese "One Belt, One Road" initiative. Together with the Kazakhstan's "Nurly Zhol" project, this line of collective cooperation is exerting an increasingly growing influence not only on the Kazakhstan's economy, but also on the economic trends of all Central Asian countries. The author conducted an original analysis of the positioning for modern economic component in China-Kazakhstan relations, examined the nature of its influence on the development of Kazakhstan's economy and further prospects for cooperation in this direction. The current crisis, indeed, forces adjustments in the plans for economic development around the world, and also raises the issue of post-crisis cooperation 
between Kazakhstan and China. It is possible to forecast the intensity of future cooperation between the two countries judging from the post-crisis development perspectives of both economies and via "One Belt, One Road" cooperation.

During the whole period of China Kazakhstan relations for more than 25 years, two countries have increasingly developed from ordinary neighbors to important strategic partners. With the continuous strengthening of exchanges and interactions, while strengthening economic and trade cooperation, infrastructure construction and exchanges between China and Kazakhstan have gradually increased, especially in the fields of science, new technologies, transportation, communications, education, which further promotes the development of bilateral diplomacy. In terms of investment, it has also played a larger role, attracting investment from China and other countries in Kazakhstan, expanding the market scope and forming a scale economy.

Since 1995, Kazakhstan began to implement the foreign policy of using its resource base with rich energy reserves as the biggest advantage and China, as a neighboring country with fast-growing economy took benefit of this fact. Therefore, China and Kazakhstan have been cooperating in the field of energy over last 30 years. However, there are still some problems in China Kazakhstan energy cooperation. Two countries need to develop more effective cooperation model to meet the requirements of the modern world. From the perspective of China, Chairman Xi Jinping emphasized that China attach great importance to the relationship with Kazakhstan and regard Kazakhstan's superiority of geographical position as the priority direction of China's diplomacy. In addition, Xi Jinping stressed that with the integration of the world economy, more and more countries have closer economic exchanges, and China and Kazakhstan are also building many joint projects [2].

The "Silk Road Economic Belt", together with the 21st century Maritime Silk Road, commonly known as the "One Belt One Road" or OBOR, (Chinese:一带一路) initiative. The One Belt refers to the overland historical Silk Road that connected China with Europe via Central Asia while One Road covers the maritime connections between China and Europe via the seas through Southeast Asia, South Asia, Middle East and East Africa. Since China proposed this initiative, Kazakhstan has responded positively, given strong support to the establishment of the Asian infrastructure investment bank and the Silk Road Fund, and the political exchanges between China and Kazakhstan become more frequent. China has expressed strong support for Kazakhstan's "Bright Road" plan (Kazakh: Nurly Zhol). In August 2015, during Ex-President Nazarbayev visit to China, substantial progress was made in the docking of the Silk Road Economic Belt and the "Bright Road". After consultation between the two sides, the joint declaration of the People's Republic of China and the Republic of Kazakhstan on the new stage of comprehensive strategic partnership was signed on August 31, 2015, confirming the consistency of the docking of China's "Silk Road Economic Belt" and Kazakhstan's "Bright Road" plan [3].

China has implemented the OBOR initiative in order to further proceed and achieve common success in the area of bilateral relations. Through China's "One Belt One Road" plan, especially with the support of infrastructure construction in Kazakhstan, it will promote Kazakhstan's "Bright Road" plan, the overall industrial development and division of labor. The connection and effective integration of the "Bright Road" and the "Silk Road Economic Belt" need to clarify the attitudes and positions of both sides, determine mutual objectives and core, focus on more docking in private sectors, build multi platform communication and shared channels and realize the diversification of cooperation fields.

Kazakhstan and China will carry out a series of cooperation in infrastructure construction, investment, trade, business and tourism, strengthen interregional connectivity, strengthen political mutual trust, and achieve mutual benefit and win-win results. A series of policies and plans put forward by Kazakhstan and China for the connection of the "Bright road" and the "Silk Road Economic Belt", which are conducive for the promoting of the effective implementation of various policies, providing political guarantee for the docking of Kazakhstan and China's economic construction, which also provides a solid foundation for the diversification of bilateral development. Kazakhstan political scientist K. L. Syroezhkin mentioned that from the perspective of Kazakhstan, firstly, this project opens the possibility of transport and logistics potential of the country; secondly, as a promising member of the WTO, Kazakhstan, to a certain extent, is quite capacious consumer market in China, which may become the locomotive of Kazakhstan's economic growth; third, Kazakhstan has dynamic economic corridor between East and West, that can be a source of transfer of advanced technologies and large investments in the country's economy [4]. 
According to the data of main import and export industries of China and Kazakhstan attached, from 2009 to 2019, the total volume of import and export trade of Kazakhstan's goods fluctuated. In 2012, Kazakhstan's foreign trade volume peaked in nearly a decade, but then entered the decline channel in 2013. In 2015-2016, Kazakhstan's foreign trade volume declined significantly due to factors such as the fall in international oil prices and the failure of the country's plan to reduce its economic dependence on raw materials. After 2017, Kazakhstan's total foreign trade picked up rapidly. In 2018, the annual import and export volume was US $\$ 74.4$ billion, up $23.4 \%$ year on year [5]. In "One Belt One Road" cooperation Initiative, China's infrastructure interconnection and international capacity cooperation are regarded as a priority areas. China has strong trade competitiveness and capacity advantages in glass, steel, plastics, cement, ceramics and other infrastructure related industries. Silk Road Economic Belt has already occupied a certain market share. China's advantageous infrastructure related industries are just in line with the huge demand of infrastructure construction in the countries along the OBOR, and are linked with Kazakhstan's "Bright Road" plan to achieve mutual benefit and common development.

"Bright road" is a policy of Kazakhstan at the national level, which is the embodiment of Kazakhstan's full use of its geographical advantages to develop transportation. The core of "Bright Road" is to emphasize large-scale investment in transportation and logistics infrastructure projects. Its purpose is to build a transportation network that can radiate regional centers all over the country, with the capital Astana as the center. The large-scale investment of "Bright Road" is made not only for the development of Kazakhstan's transportation system, but also to demonstrate Kazakhstan as a biggest transportation corridor which can connect markets in Central Asia, China, Russia, Europe and the Middle East. The implementation of the "Bright Road" plan will not only effectively promote economic growth, but also create a large number of jobs, which will have strong influence on labor market. Since the implementation of the plan, only highway construction and reconstruction projects have created more than 100.000 jobs. The implementation of the "Bright Road" plan has played a positive role in the national economic growth, which is not only reflected in ensuring the stable tax revenue source of the national finance, but also promoting the development of construction, service, commerce, communication and other industries.

There are many similarities between the "Bright Road" and the "Silk Road Economic Belt". They are complementing each other and are important footstones for each other. After the docking of the "Bright Road" and the "Silk Road Economic Belt", China will provide Kazakhstan with largescale equipment and materials, which will greatly promote the development of China's industrial machinery manufacturing and other metal products, especially the development of China's infrastructure construction enterprises. At the same time, a large number of new factories and equipment will be built in Kazakhstan, which can meet the material and equipment requirements for infrastructure construction within "Bright Road" plan. It will assist to promote the development of relevant industries in Kazakhstan, increase more relevant job opportunities, refine the division of labor and cooperation in industrial chain layout, which will support the cooperation with China and other countries along the Silk Road Economic Belt in the division of international industrial chains; will seize more international markets, develop more and more detailed domestic industries, and promote the quality and quantity development of Kazakhstan's overall economy.

Driven by the countries along the Silk Road Economic Belt, the common integration of the "Bright Road" and the "Silk Road Economic Belt" will not only promote the economic construction of Kazakhstan and China, but also maintain the orderly allocation of resources and the free flow of economic elements, achieve regional integration of resources, and achieve the goal of cross regional economic integration. In view of the fact that the "Bright Road" and the "Silk Road Economic Belt" are highly consistent in their time and space objectives and their concepts and objectives are all centered on the development of domestic transport networks and interregional partnerships, Kazakhstan and China hold high the same banner for these two economic policies and initiatives.

Lousianin, S.G. and Afonasyeva A.V referred that Kazakhstan has high aspirations in China's "One Belt and One Road" initiative, because it is the ideal intersection between China and West, and its interest in OBOR is indisputable. The Kazakhstan government has been involved in the Nurly Zhol "The Road of Light". "Bright road" is a 9 billion US dollar domestic economic stimulus plan, which aims to build roads and transform roads, railways, etc [9]. In addition, Kazakhstan is vital to China's energy security. Its oil, natural gas, coal and uranium reserves rank among the top 10 in the world, and 
it has a strategic geographical location to control the flow of materials from Central Asia to East and West Asia [6].

Zh. Bagitzhanova, G. Jumadilova, A. Chaukerova [8] "One Belt, One Road" initiative researchers from Kazakhstan were doing investigation on the aspects of China's "One Belt and One Road" in the contemporary international relations and the impact on Kazakhstan's domestic economic development and bilateral trade relations. The authors describe China's priority interest areas in Kazakhstan and point out that China chose Kazakhstan to promote the concept of "Silk Road Economic Belt". Chinese leaders regard Kazakhstan as a very important and promising trade and economic partner in Central Asia. They also mentioned a very important part of the upcoming project: investment in infrastructure in Kazakhstan. Kazakhstan's government, together with its Chinese partners, has invested heavily in strengthening its position as a transit corridor, including $\$ 3.5$ billion in the dry port "Khorgos East Gate" on its eastern border with China. COSCO Shipping, one of the world's largest logistics service providers, and Lianyungang holding group recently acquired a stake in the project, making it transnational and giving Kazakhstan an opportunity to benefit from the valuable experience of its partners. The main point of their research is that infrastructure investment and follow-up benefits have become the main growth engine of Kazakhstan's Cross continental trade and economy.

The official policy of the Chinese government is reflected in Chinese scientists' works $[5,11$, 12,]. In the biggest part of currently publications, they pointed out that speeding up the construction of the "One Belt, One Road" plan will contribute to economic development, promote regional interaction, and enhance cultural exchanges among countries along the Silk Road Economic Belt. For all countries involved, OBOR will have a clear purpose of peacekeeping and common development. The further implementation of the "One Belt, One Road" project must be based on the principles of comprehensive consultation, cooperation and mutual benefit, and strive to further develop the integration strategy among Member States. China's "One Belt, One Road" construction is an inevitable requirement for building a new pattern of China's all directional opening up and is an inevitable choice for promoting the common development and prosperity of Asian and European countries, Chinese scientist Yuan Xintao mentioned [10].

This construction strategy has been actively supported and participated by Asian and European countries, and relevant provinces in China have formulated implementation plans. However, the strategic measures taken by the United States, Russia and Japan to dominate regional affairs have brought severe challenges to the construction of the Belt and Road initiative. Countries along the belt and road should unite with each other for mutual trust, win-win cooperation, strive to build an Asia Europe Community of interests and a community of common destiny, and jointly create a new brilliance of the Silk Road. Gong Wen, Tian Junrong and Wang Ke mentioned in the article "New Silk Road: towards common prosperity [13] that the development of the project will bring economic advantages to China and all participants. We will strengthen policy communication, road connectivity, unimpeded trade, currency circulation, and people to people connectivity - "five links", which will have a bright future. One Belt, One Road, has been actively responding to the Silk Road consciousness. The air plant has begun to link its own development strategy with the "One Belt And One Road". Some cooperative projects have come to fruition. The upsurge of relevant domestic provinces and cities is surging: Xinjiang is positioned as the "core area", Shaanxi creates a "new starting point", Gansu operates the "golden section", and Guangxi strives to be the "forerunner" From the line to the piece, the new Silk Road is boosting regional cooperation.

Among all the factors affecting Kazakhstan China relations, geographical location is perhaps the most obvious, but at the same time, for many reasons, it is still one of the most in-depth and influential factors. First of all, the whole Central Asia region is related to China's national interests. It is worth noting that China's foreign policy has a clear geographical priority, that is, the countries bordering China are the most important countries in the development of relations. This is understandable Pragmatism: there is a belt of friendly countries around the borders of any country, which makes it possible to maintain stability without participating in border conflicts. As one of the major trading countries, China's interest in it is unique. Kazakhstan is one of the important countries in Central Asia, and plays a special role in this regard, especially in the development of border trade, the establishment of special zones, such as the International Center for cross-border cooperation "Horgos" (ICBC "Horgos"), and investment in joint infrastructure such as roads and railways. But most 
importantly, Beijing's peaceful geopolitical interests on the western border have created a favorable background for Kazakhstan China political relations.

Kazakhstan is rich in natural resources, especially mineral resources. Many energy and mineral reserves account for a high proportion of global reserves, such as tungsten over $50 \%$, uranium $25 \%$, chrome ore $23 \%$, lead $19 \%$, zinc $13 \%$, copper and iron $10 \%$. See Table 1 for specific reserves ranking. In addition, Kazakhstan's oil and natural gas reserves are very rich. According to the data released by the Kazakhstan Reserves Committee, at present, Kazakhstan's oil recoverable reserves are $40 \times 108 \mathrm{t}$ and natural gas recoverable reserves are $3 \times 1012 \mathrm{~m} 3$. However, as a major energy producer, its consumption capacity is extremely limited. According to BP world energy statistics yearbook 2017, Kazakhstan consumed $19.2 \%$ of its oil production and $67.3 \%$ of its natural gas production in 2016 . There is no domestic demand for uranium resources, that is, more than half of the oil and gas resources and all uranium resources are used for export.

Table 1. Global Ranking of Kazakhstan mineral reserves, source: http://www.nationalbank.kz/

\begin{tabular}{|c|c|c|c|c|c|}
\hline $\begin{array}{c}\text { Mineral } \\
\text { resources }\end{array}$ & $\begin{array}{c}\text { World } \\
\text { ranking }\end{array}$ & Reserves & $\begin{array}{c}\text { Mineral } \\
\text { resources }\end{array}$ & $\begin{array}{c}\text { World } \\
\text { ranking }\end{array}$ & Reserves \\
\hline Wolfram & 1 & $200 \times 10^{4} \mathrm{t}$ & $\begin{array}{c}\text { Chromium } \\
\text { ore }\end{array}$ & 2 & $4 \times 10^{8} \mathrm{t}$ \\
\hline Uranium & 2 & $150 \times 10^{4} \mathrm{t}$ & $\begin{array}{c}\text { Manganese } \\
\text { ore }\end{array}$ & 4 & $6 \times 10^{8} \mathrm{t}$ \\
\hline Copper & 4 & $3450 \times 10^{4} \mathrm{t}$ & Zinc & 4 & $2570 \times 10^{4} \mathrm{t}$ \\
\hline Iron Ore & 6 & $91 \times 10^{8} \mathrm{t}$ & Lead (Pb) & 6 & $1170 \times 10^{4} \mathrm{t}$ \\
\hline Gold & 8 & $1900 \mathrm{t}$ & Aluminum & 10 & $4.5 \times 10^{8} \mathrm{t}$ \\
\hline
\end{tabular}

Starting from the successful bidding of Aktobe oil field development project by CNPC in 1997, China's capital and technology began to enter Kazakhstan market. At present, China's three major oil companies and a number of private oil and gas enterprises have carried out project cooperation in oil and gas business with Kazakhstan, such as Petro Kazakhstan (PK) project of China-Kazakhstan oil pipeline project, Aidan MUNAI (ADM) project, Kuatamlonmuani (KAM) project, etc. "One Belt, One Road" initiative, as 20 years ago, is continuing outstanding energy cooperation between China and Kazakhstan and emerging it as a model of mutual benefit and win-win for the two countries.

At the founding meeting of the China Kazakhstan Entrepreneurs Committee (2013), China's Chairman Xi Jinping pointed out that pragmatic cooperation between China and Kazakhstan was fruitful and created many "outstanding events"[9]. China is Kazakhstan's largest trade partner and Kazakhstan is China's largest investment object in the Commonwealth of Independent States (CIS) region. China-Kazakhstan crude oil pipeline is China's first land-based transnational crude oil pipeline, and there are numerous successful examples of cooperation between the two countries. These cooperation achievements have not only brought tangible benefits to the Chinese and Kazakh people, but also provided unremitting motion for the sustained development of the comprehensive strategic partnership between the two countries. In his speech, President Nazarbayev pointed out that Kazakhstan-China oil and gas cooperation, especially the Kazakhstan-China crude oil pipeline and Kazakhstan-China natural gas pipeline, are the concrete embodiment of the "Silk Road Economic Belt" and the achievements witnessed by the two heads of state.

For Kazakhstan, which is located in the center of Eurasia and has no sea passage, China's transcontinental initiative offers new prospects and opportunities. By developing its transit potential, Kazakhstan seeks to occupy its geo economic niche and become a major bridge between the economic growth poles of Asia, Europe and the Middle East. At present, more than $60 \%$ of the world's GDP is concentrated in these economic growth poles. In turn, the transit route through Kazakhstan territory opened up a channel for China to enter the European, Middle East and CIS markets, forming an economic corridor between China, Central Asia, Western Asia and China Indochina. About 50\% of the transit traffic between China and Europe passes through Kazakhstan.

China's "One Belt One Road" initiative is the most influential partnership for Kazakhstan. Kazakhstan is a key component of this initiative, led by the Chinese government. The construction of Khrogos gateway is perhaps the best example of this project. This is a specially designed port, far away from any large water area, where goods can be unloaded from trains rather than ships. This special 
infrastructure investment project is so attractive because it is located in the middle of the desert and needs to build a new town, Nurkent, which once housed all the new employees in the "dry port". The Chinese government has been active in this investment because they urgently need to set up new transit stations along the Silk Road under construction. Investments like this are seemed to be risky from several sides, but Kazakhstan Leader of the Nation N. Nazarbayev has been a strong advocate of the project because he and other leaders want to expand Kazakhstan's position as the region's growing market power.

During last 5 years, China Kazakhstan economic and trade cooperation has been deepening. In 2017, the bilateral trade volume between China and Kazakhstan reached US \$18 billion, a year-onyear increase of $37.5 \%$, and the stock of direct investment in Kazakhstan reached US \$7.561 billion at the end of 2017[6]. China's investment in Kazakhstan involves agricultural and sideline products processing, leather processing, oil exploration and development, etc., while Kazakhstan's investment in China mainly involves building materials, leather, food, etc. In general, the main investment areas are in Xinjiang, and the economic and trade cooperation between China and Kazakhstan has achieved substantial results in many fields.

In addition, China's cooperation with the "China Central Asia West Asia" economic corridor countries has been deepening, especially in the field of infrastructure connectivity. Kazakhstan can take advantage of China's extensive cooperation with other countries along the "Silk Road Economic Belt" in Central Asia, participate in more industrial division and cooperation, take advantage of Kazakhstan's leading political position in Central Asia, with its vast territory, abundant natural resources and other advantages, and introduce more Chinese enterprises to develop Kazakhstan's related industries, refine the domestic and international division and cooperation of the industrial chain, and cultivate more competitive industrial reserve forces.

In terms of economy and trade, despite the difficulties in the world economy in 2015, China is still Kazakhstan's main economic partner. From the Figure 1, we can see that in 2014, the total amount of foreign direct investment into Kazakhstan was 211 million US dollars, and China invested 108 million US dollars. In early 2015, China's total foreign direct investment in Kazakhstan increased from US \$45 million in 2005 to US \$984 million. In 2014 and 2015, the trade volume of the two countries exceeded US \$1.2 billion and US \$1.1 billion respectively. Since 1992, China has provided 1.8 billion Yuan (about 274.4 million US dollars) and 1.8 billion US dollars of loans to Kazakhstan for financing several projects [6]. The cooperation projects of the two countries include: natural gas pipeline between Kyrgyzstan and China, phase II project of the North South Highway, reconstruction and repair of Bishkek Road, construction of domestic oil refineries, modernization of Bishkek power station, etc.

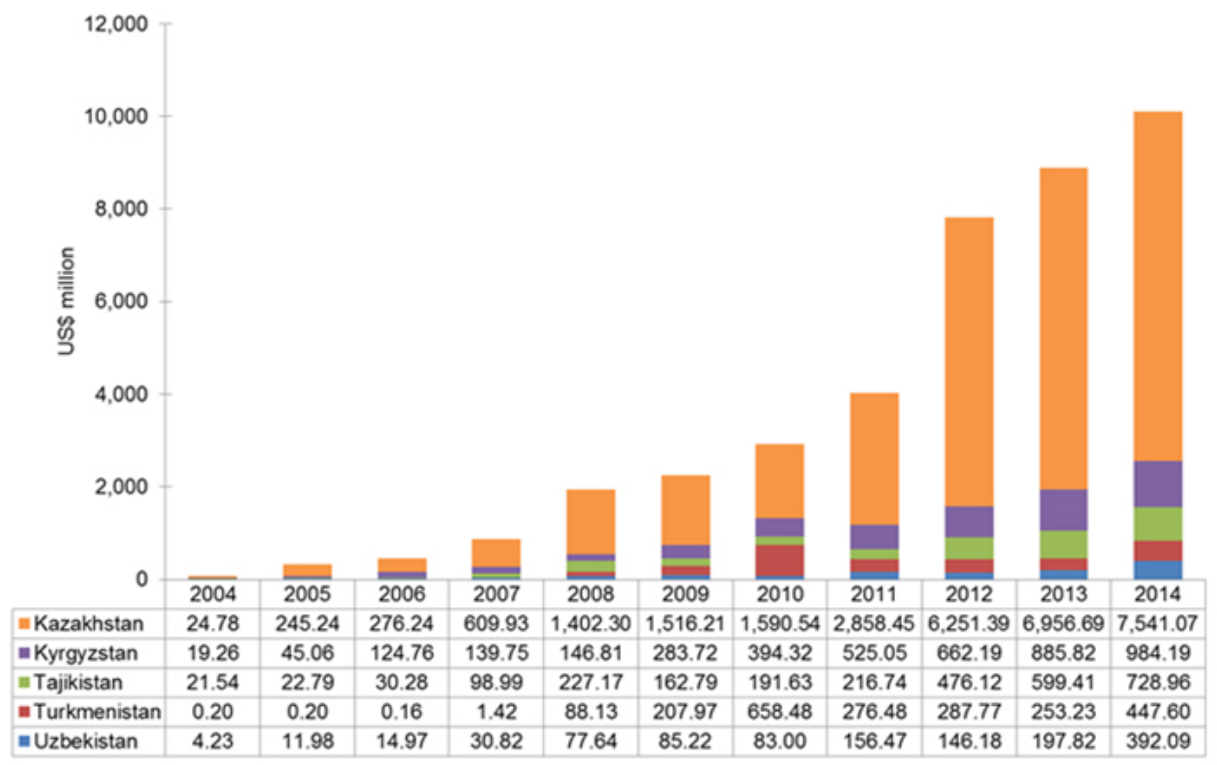

Fig. 1. China's Stock of Outward Direct Investment to Central Asia (2004-2014), source: Statistical Bulletin of China's Outward Foreign Direct Investment

The bilateral cooperation agreement signed by the Prime Minister of Kazakhstan during his official visit to China on January 12, 2016 provides conditions for the development of international 
trade. According to the agreement, the two sides agreed to build China-Kyrgyzstan-Uzbekistan Railway and the Issekkor ring road to deliver more Chinese products to Kazakhstan. With the development of China-Kyrgyzstan trade relations as the goal, the unemployment rate in Kazakhstan can be reduced through the establishment of new industrial facilities with the above-mentioned project funds of China. It is worth noting that Kazakhstan's investment inflow has increased, which is one of the economic opportunities provided by China's Silk Road Economic Belt Project. Kazakhstan has signed more than 10 investment agreements with China with a total amount of US $\$ 1.812$ billion (excluding grant assistants). In the early 1990s, it mainly invested in real estate and industrial construction (Kyrgyz-China paper mill).

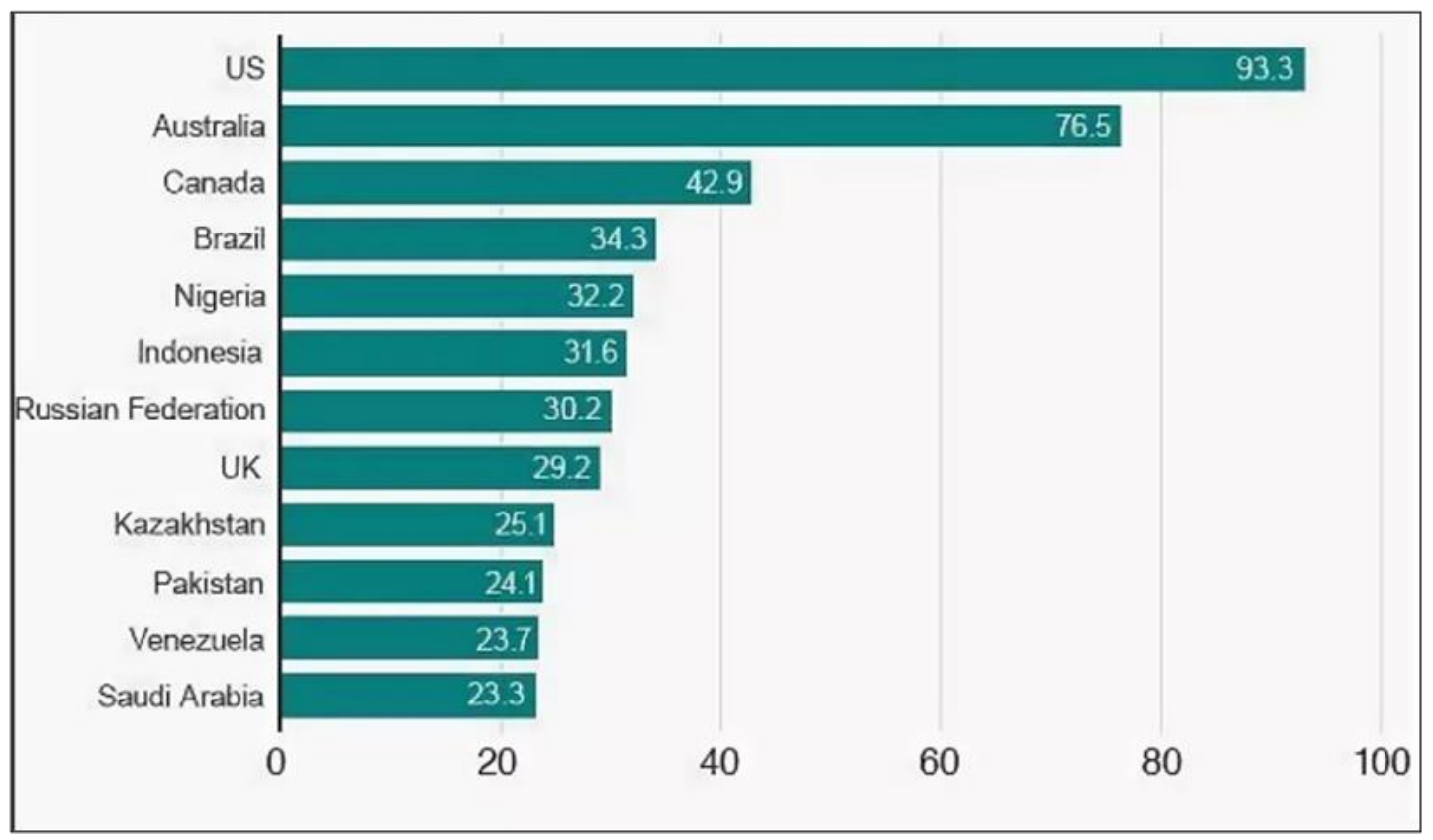

Fig. 2. Top destinations for Chinese investment 2014-2018, (investment and contracts US billion), source: The American Enterprise Institute/The Heritage Foundation

In the past 10 years, highway repair (China has invested more than $\$ 129$ million in this area) and energy sector have become priority investment areas. From the Table 2 we can see that Kazakhstan is taking the 9th place in the ranking of Chinese investments, conceding to Russia and the UK. In fact, China has recently invested mainly in Kazakhstan's energy sector. The most important joint energy project is the reconstruction of Bishkek power station. China has allocated more than \$386 million for the project through TBEA (Tebian Electric Apparatus, is a Chinese manufacturer of power transformers and other electrical equipment). In addition, the State Power Investment Corporation of China and the government of Kazakhstan have held talks on the construction of Kazarman chain hydropower station on the Narin River. If the project with a total investment of more than US $\$ 1.565$ billion is implemented, it is expected to become China's largest investment in Kazakhstan's energy sector.

Conclusions. For Kazakhstan, which is located in the center of Eurasia and has no sea passage, China's transcontinental initiative offers new prospects and opportunities. By developing its transit potential, Kazakhstan seeks to occupy its geo economic niche and become a major bridge between the economic growth poles of Asia, Europe and the Middle East. At present, more than $60 \%$ of the world's GDP is concentrated in these economic growth poles. In turn, the transit route through Kazakhstan territory opened up a channel for China to enter the European, Middle East and CIS markets, forming an economic corridor between China, Central Asia, Western Asia and China Indochina. About 50\% of the transit traffic between China and Europe passes through Kazakhstan. Within the development of OBOR, the economic ties of Central Asian countries are become more effective which once again proves the advantages and farreaching prospects of joint cooperation under this project. These developments seem to be in Kazakhstan's favor: Kazakhstan needs new trading partners in order to exploit its huge resource potential and become one of the world's five largest oil producing countries, but it is also committed to economic diversification, and investment in other sectors, such as renewable energy, helps to achieve this goal. For many years, 
Kazakhstan's trade relations with China have been limited to natural gas and oil exports, but at present, trade is gradually diversifying, which has a positive impact on the economic interconnection between the two countries, especially in the border areas. The improvement of bilateral relations between China and Kazakhstan highlights these developments and may help consolidate the achievements of the largest central Asian republic in the short term. Kazakhstan and China are developing transport and infrastructure and increasing transit and logistics capabilities. Therefore, it is possible to implement some Kazakh projects through the Silk Road regional project.

As a result, Kazakhstan and China are continuing to strengthen cooperation in various fields. The platform for this relationship has developed over the years of independence and has accumulated serious potential for stability. Even now, in the context of the crisis of international relations and the trade barriers of the Eurasian Union, it has not had a negative impact. On the contrary, it has brought positive impetus to the development of this relationship. That's why China attaches great importance to Kazakhstan, which has become a key factor in Beijing's overall Central Asian policy.

\section{REFERENCES}

1. Gorse, I. "Kazakhstan and China Sign Oil and Gas Pipelines Agreement", Financial Times, August 20, 2007: 50-52.

2. Jinping, Xi. Carry forward the five principles of peaceful coexistence and build a win-win world of cooperation / Xi Jinping's Speech at the 60th anniversary of commemorative meeting on the five principles of peaceful coexistence.: People's daily, 2014. P. 2 (习近平, 弘扬和平共处五项原则建设合作共赢美好 世界一在和平共处五项原则发表 60 周年纪念大会上的讲话 [N] . 人民日报， 2014，页 2.

3. Reeves J. Imperialism and the Middle Kingdom: the Xi Jinping administration's peripheral diplomacy with developing states / J.Reeves.: Third World Quarterly, 2018

4. Syroezhkin, K.L. China's presence in Kazakhstan: myths and reality / K.L. Syroezhkin .: Central Asia and the Caucasus 12, no. 1, 2011. pp.101-114.

5. Xiao L., Yibing D. From export platform to market provider: China's perspectives on its past and future role in a globalised Asian economy / L. Xiao, D. Yibing.: Third World Quarterly, 2015

6. Lousianin, S.G, Afonasyeva A.V. Belt and road initiative - political and economic dimensions / S. G. Lousianin, A.V. Afonasyeva.: Tomsk State University Journal of Economics, no. 40, 2017. pp. 5-14.

7. Xiuping Z., Corrie B.P. Investing in China and Chinese investment Abroad / Z.Xiuping, B.P. Corrie.: Springer Science and Business Media LLC, 2018

8. Zh. Bagitzhanova, G. Jumadilova, A. Chaukerova L.N., China's «One Belt - One Road» Initiative, Gumilyov Eurasian National University, 2017, https://www.pwc.kz/en/publications/new-2017/silk-waypublication-rus.pdf.

9. Wang Ye, Chinese President Xi Jinping delivers a keynote speech at the opening ceremony of the Belt and Road Forum (BRF) for International Cooperation in Beijing, capital of China, May 14, 2017. (Xinhua Agency) http://xinhuanet.com/english/2017-05/14/c_136282982.htm

10. Yuan Xintao One Belt, One Road "National Strategy Analysis", [J]. Xi'an Jiao Tong University, 1004-0544 (2014) 11-0005-05.

11. Zheng L., Liu Z G. (2015). Spatial pattern of Chinese outward direct investment in the Belt and Road Initiative area. Progress in Geography, 34 (5): 563-570. https://doi.org/10.11820/dlkxjz.2015.05.004 (In Chinese).

12. Zhou, W. and Esteban, M. (2018) Beyond Balancing: China's Approach towards the Belt and Road Initiative. Journal of Contemporary China, 27, 1-15. https://doi.org/10.1080/10670564.2018.1433476

13. 龚雯, 田俊荣, 王珂.新丝路:通向共同繁荣 [N].人民日报, 2014- 06-30 (1) Gong Wen, Tian Junrong, Wang Ke. New Silk Road: towards common prosperity [n]. People's daily, 2014-06-30 (1) 